\title{
Improvement of Degraded Pastures in the Foothills and Sandy Desert Zone of Uzbekistan by Implementing Best Practices
}

\author{
Farmanov T. (Corresponding author) \\ Research Institute of Agricultural Economics, Tashkent, Uzbekistan \\ E-mail: farmonov@rambler.ru \\ Mukhtorov A. \\ Research Institute for Agricultural Economics Tashkent, Uzbekistan \\ Mukimov T. \\ Samarkand State University, Samarkand, Uzbekistan
}

\begin{abstract}
The article presents the best practices for the restoration of degraded pastures in the foothill zone of the Zamin district of Jizzak region and the sandy desert of Karakul district of the Bukhara region carried out by a UNDP project. On the degraded lands, measures were taken to restore the biodiversity of pastures, preserve landscape-ecological systems. The implementation of reclamation measures for the retention of moving sands, for the creation (restoration) of protective forest belts in pastures, reproduction of pasture productivity by artificial by additional sowing seeds in degraded areas, restoration of pasture infrastructure, bringing non-working wells and wells into working order.
\end{abstract}

Key words: foothills, Kyzylkum desert, degradation, drought-resistant fodder plants, seeds, seedlings, technology, grazing

DOI: $10.7176 / \mathrm{JSTR} / 6-10-12$

\section{Introduction}

Karakul pastures of Uzbekistan, occupying about 23.5 million hectares, are the main source of food for Karakul sheep, goats, and for camels. These pastures are located in different soil and climatic conditions: gypsum, saline, sandy, etc. Characteristic climatic features are a low amount of atmospheric precipitation - from 80 to $250 \mathrm{~mm}$ per year; high temperatures in summer (38-450C and above), low in winter months (minus $-10-15^{\circ} \mathrm{C}$ and below).

These pastures are suitable for use throughout almost the entire year, are characterized by a variety of pasture, relatively high nutritional value and provide the cheapest feed [1]. The ecological and biological potential of forage plants determines the productivity of desert pastures in the range of 0.18 $0.35 \mathrm{t} / \mathrm{ha}$.

Inadequate management, long-term, strong overgrazing have caused depletion of pastures, degradation of vegetation and soil cover, disruption of the hydrological regime, and desertification. Pasture resources are limited, and therefore competition for their use is growing. The natural vulnerability of the arid zone pasture ecosystems is enhanced by the actions of the local population, for whom animal husbandry is one of the main sources of income.

Over-concentration of livestock per unit area and ineffective extensive livestock management are the main causes of overgrazing, reduced productivity and pasture degradation. One of the signs of pasture degradation is an increase in the degree of weedy plants area, an increase in the abundance and area of thickets of poisonous, inedible and weedy species - Phlomis trapsoides, Peganum harmala, Heliotropium argusioides, Psoralea drupaceae and others. At the same time, the abundance and productivity of the main forage plants decreases, and, accordingly, the productivity of farm animals decreases.

Land degradation and desertification are becoming one of the most important environmental problems that threaten natural ecosystems and socio-economic development of the Republic of Uzbekistan.

143 | P a g e

www.iiste.org 
Desert pastures of Uzbekistan, being a part of pasture animal husbandry in Uzbekistan, are based on low-productive pastures and occupy a special place in the country's economy as the main means of economic development of deserts, and at the same time act as the main source of live-support and wellbeing of the population living here.

Purpose of the study. A consistent increase in the productivity of degraded pastures in the foothill and desert zones by under sowing plants, increasing biodiversity, introducing technologies for the restoration of pastures, ensuring the defensive strip for a long time.

Materials and research methods. The project focused on two agrolandscapes prone to degradation: (1) foothills in the Zamin district of the Jizzakh region and (2) low-productive sandy pastures in the Karakul district of the Bukhara region.

In order to increase the productivity of degraded lands, the best practices of sustainable land management were applied in the following areas: Restoration and conservation of pasture biodiversity: - restoration of the productivity of pastures and their production infrastructure to prevent the degradation of pastures, restore and preserve landscape-ecological systems, improve the quality of the environment in the area;

- Implementation of reclamation measures for the strengthening of moving sands, for the creation (restoration) of protective forest belts in pastures;

Reproduction of pasture productivity by artificial under sowing in degraded areas;

- restoration of pasture infrastructure, bringing non-working wells and bore well, sheepfold, road networks and bridges, technical anti-erosion structures into working order;

\section{Results and Discussion.}

Foothill semi-desert. The pasture areas of the foothill zone of the Zamin district of the Jizzakh region are deprived of semi-shrub and shrub vegetation; due to the excessive load, it is necessary to intensify fodder production here. For this, it is necessary to establish seed production and create multicomponent, highly productive artificial hay meadow.

Photos 1 and 2 show natural pastures and improved pastures foothill zone of the farm in Zamin district.

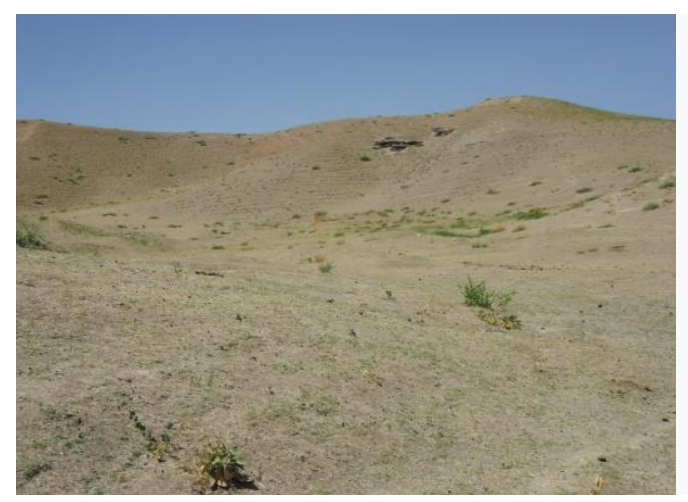

Photo 1. Natural pastures

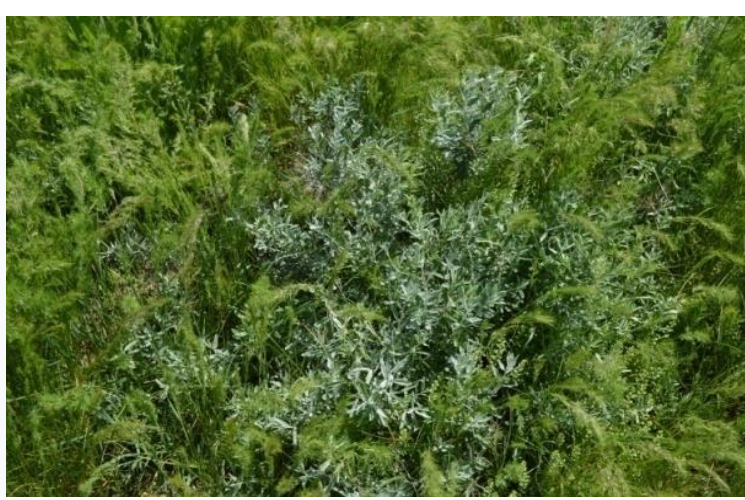

Photo 2. Improved pastures

Livestock farms annually harvest and purchase livestock for the winter (about 30-40\%) in a very large volume of coarse and concentrated feed, which significantly reduces the efficiency of animal husbandry, contributes to an increase in the cost of production and a decrease in the profitability of animal husbandry, in dry years, a sharp reduction in the number of livestock. In general, there is usually an acute shortage of forage in the foothill pastures in the autumn-winter season. On this type of pasture, plants such as Carex, Poa bulbosa, and other ephemeroids and ephemeral mainly develop.

The top layer of the soil is firmly bound by powerful sod of Poa bulbosa. Powerful sod is one of the reasons for the extinction of shrubs and semi-shrubs. Thus, in the foothills there are spring and summer pastures, and there is a lack of autumn and winter ones.

Within the framework of the UNDP Project "Reducing the pressure on natural resources from Competing Land use in non-irrigated Arid Mountain, Semi-desert and desert landscapes of Uzbekistan

144 | P a g e

www.iiste.org 
(Land)", work was carried out to enrich the pastures of the «Rustamnoma» farm in the Zamin district of the Jizzakh region.

The yield of natural pastures in most of the district does not exceed 0.03-0.05 t/ha. The average annual yield of pastures is low $-0.25-0.30 \mathrm{t} / \mathrm{ha}$. On pastures, weedy, low-eaten plants grow in large numbers, the yield of non-eaten and harmful plants is $0.23 \mathrm{t} / \mathrm{ha}$. [3] For enrichment of pastures by strip method, seeds of 6 species of perennial drought-resistant forage species were sown on an area of 50 hectares, the area of coverage of pastures with inter-strip spaces were 450 hectares. [5].

Usually in the foothills there are spring and summer pastures, and there is a lack of autumn and winter; pastures have been created here and full-fledged wintering lands on them from fodder semi-shrubs and shrubs. On this territory, as a result of the fence, many species of forage plants have survived and appeared, increased biodiversity. In subsequent years, the farm's livestock grazed on its territory, where drought-resistant forage crops were planted and herbage was preserved. One-time costs of the farm for improving pastures in 2-3 years pay off: the productivity of pastures for a long time (15-20 years) without further costs remains at a high level, provided that the pastures are properly exploited.

In subsequent years, with the spread of seeds of fodder crops and, accordingly, with an increase in yield in this area up to 1.2-1.4 t/ha, it will be possible to keep 700 heads of sheep during the year, without the cost of purchased feed. These pastures have been used for 20-25 years, but with proper use, i.e. grazing $70-75 \%$ of the plant mass and the possibility of sowing plants, they can be used for a long time.

Aellenia subaphylla. The following types of perennial drought-resistant forage crops have been sown on the strips: Aellenia subaphylla (C.A. Mey) Aellen, $70 \mathrm{~cm}$ high shrub $-2.0 \mathrm{~m}$ from the haze family Chenopodiaceae (photo 4). The root system of Aellenia subaphylla is powerful, deeply penetrating into the soil of a universal type. Designed for pasture use. Productive longevity 15 years. It is very drought and salt tolerant, resistant to diseases and pests, to intensive grazing, highly competitive. The growing season is 240 days.

The yield of dry fodder mass is 1.0-1.5 t/ha, seeds are 0.2-0.3 t/ha. It is well eaten in autumn-winter periods, satisfactory in spring and summer. $100 \mathrm{~kg}$ of hay is nutritionally equal to 42 of fodder units and contains $20 \%$ protein to $2.5 \%$ fat. Recommended for cultivation on gray-earth, brown and sandy soils of weak and medium salinity, with an amount of atmospheric precipitation of 80 to $400 \mathrm{~mm}$.

A perennial species of Atriplex - Atriplex undulata - a perennial semi-shrub from the family of Chenopodiaceae. Plant height is $100-120 \mathrm{~cm}$. Bushiness and foliage are good. They have a long vegetative season of 250-280 days. The survival rate of individuals in the arid zone of Uzbekistan is high - $85-90 \%$. The palatability is good. The yield of dry fodder mass Atriplex undulata forms 1.2-1.8 $\mathrm{t} / \mathrm{ha}$ of fodder and $0.25-0.35 \mathrm{t} / \mathrm{ha}$ of seeds.

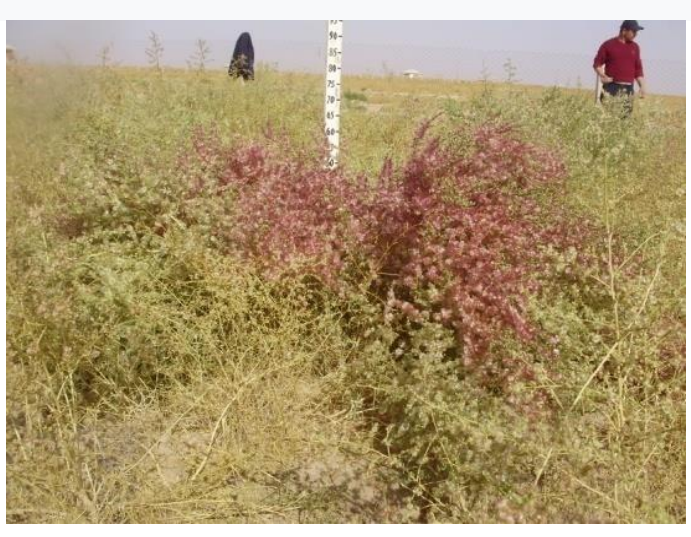

Photo 4. Aellenia subaphylla

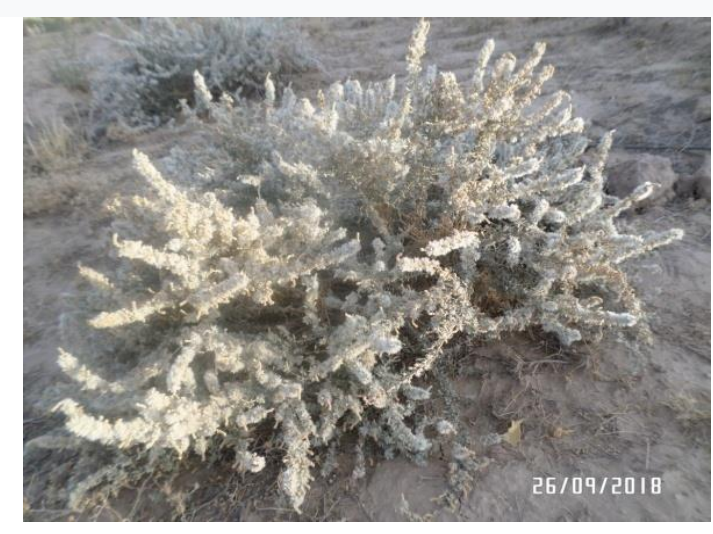

Photo 5. Ceratoides eversmanniana

Ceratoides eversmanniana Botsch, et Ikonn. - Is a semi-shrub from the family of Chenopodiaceae, $65-85 \mathrm{~cm}$ high, extremely drought and heat-resistant to diseases and pests (photo 5). Differs in high resistance to trampling, well eaten by farm animals, especially Karakul sheep and goats. $100 \mathrm{~kg}$ of feed contains $41-43$ fodder units. The vegetative season is $230-240$ days. The yield of dry fodder mass is 1.12-1.25 t/ha, the yield of seeds is $0.12-0.17 \mathrm{t} / \mathrm{ha}$. Ceratoides eversmanniana seeds remain germinability for up to 2.5 years. It competes well in co-growth with other types of forage plants. Productive longevity - 17-23 years.

$145 \mid \mathrm{P}$ a g e

www.iiste.org 
Kochia prostrata (L) schrad is a semi-shrub from the family of Chenopdiaceae, $30-75 \mathrm{~cm}$ high, in culture it often reaches $60-90 \mathrm{~cm}$ higher. Kochia prostrata is an ecologically plastic plant that grows on light chestnut and chestnut soils, light and typical gray soils of various texture: gray - brown and sandy soils.

The Kochia prostrata develops a powerful deeply penetrating (up to 5-6 m) root system of a universal type, uses the moisture of a large volume of soil. It is a drought-resistant plant that economically consumes moisture for transpiration, is demanding for heat and light, and withstands medium soil salinity.

Productive longevity is 15-20 years. The maximum yield of forage mass and seeds in culture is observed at 3-4 years of age.

The Kochia prostrata (var.canescens Mog) ecotype can be cultivated on sandy loam and loamy soils of the foothills. The seed yield is $160 \mathrm{~kg} / \mathrm{ha}$. The ecotype (var. Virescens Fenzl.) is suitable for cultivation on loamy and sandy loam soils of the foothill and wormwood - ephemeral desert. Ecotype of Kochia (var. Villossima Bond. Mey), characterized by white-shaggy pubescence, can be cultivated on sandy soils.

The seed yield is about $150-160 \mathrm{~kg} / \mathrm{ha}$. Kochia prostrata is well eaten by all types of farm animals throughout the growing season. Depending on the seasons (from spring to winter, $100 \mathrm{~kg}$ of absolutely dry feed contains $83.5-45.9$ fodder units.) [2] It is characterized by a high intensity of regrowth after mowing, drought and heat-resistant, well withstands double pasture and hay use. Artemisia is a semi-shrub from the Asteraceae family, 20-60 cm high. The growing season begins in late February, early March. In September, plants grow leaves, and the growing season continues. Flowering in September-October, seeds ripen in November. Propagates is well by seeds. On pastures, life duration is $12-25$ years. The vegetative season is 240-280 days; the root system penetrates to a depth of $2.5 \mathrm{~m}$. In desert animal husbandry, Artemisia is one of the best forage plants. $100 \mathrm{~kg}$ of hay contains 18-66 fodder units during the growing season. In many pastures, the basis (more than 50\% of the gross stock) of forage is Artemisia plants. On some types of pastures, the yield of Artemisia is 0.4$0.8 \mathrm{t} / \mathrm{ha}$.

Agropyron Gaertn is a perennial herb from the Poacea family. The root system is fibrous, penetrates into the soil to a depth of $2-2.5 \mathrm{~m}$. The stem is hollow, well leafy, $50-80 \mathrm{~cm}$ high, sometimes more. The yield of dry fodder mass is $0.86-1.44 \mathrm{t} / \mathrm{ha}$. Seed yield 0.1-0.15 t/ha. Designed are for cultivation in foothill zone of Uzbekistan with an annual precipitation of $210 \mathrm{~mm}$ and more.

Onobrychus Chorossanica Bge is a perennial herb from the Fabaceae family. It occurs wild in the foothill semi-desert conditions. Plant height is $50-60 \mathrm{~cm}$ in natural pasture, $60-80 \mathrm{~cm}$ in culture. The yield of dry fodder mass is 1.2-1.5 t/ha. Onobrychus Chorossanica is one of the highly nutritious forage plants capable of growing in foothills, where the amount of precipitation ranges from 200-240 $\mathrm{mm}$ per year. He is a representative of the wild flora and is not widespread.

Table 1. Yield and life expectancy of forage crops

\begin{tabular}{|l|l|l|}
\hline Name of fodder crop & Yield, $\mathrm{t} / \mathrm{ha}$ & Life duration, year \\
\hline Aellenia subaphylla & $1.4-1.6$ & $15-25$ \\
\hline Kochia prostrata & $1.2-1.4$ & $15-20$ \\
\hline Atriplex undulata & $1.2-1.8$ & $6-8$ \\
\hline Ceratoides eversmanniana & $1.4-1.6$ & $20-25$ \\
\hline Artemisia diffusa & $0.8-1.2$ & 3 \\
\hline Agropyron Gaertn. & $1.2-1.4$ & 40 and more \\
\hline Onobrychus Chorossanica & $0.6-0.8$ & 20 \\
\hline
\end{tabular}

The created agrophytocenoses using shrub and semi-shrub vegetation reduce the speed of winds, retain snow and protect the soil from deflation, create a milder microclimate in the cenosis itself and in adjacent areas of pastures. This, in turn, creates more favorable environmental conditions for the growth and formation of a relatively large yield of pasture fodder and the development of other plant species. The use of these methods allows increasing the biodiversity and, accordingly, the feed stock of pastures by 2-3 times. 
Sandy desert. Pasture animal husbandry in Uzbekistan is diversified in structure and is deployed in regions with low natural resource potential. The desert climate is very hot, arid, with rainfall of the order of 100-250 mm/year. The air temperature in summer rises to $+45,+50^{\circ} \mathrm{C}$, and the surface heats up to $80^{\circ} \mathrm{C}$. The vegetation cover in these conditions is thinned, consists of ephemeral and semi-shrub vegetation, adapted to a hot and dry climate.

An effective method for improving natural pastures in the desert zone is pasture protection belts, which create more favorable conditions for the growth and development of native vegetation (soften the microclimate, promote the accumulation of soil moisture, reduce the speed of winds, and protect the soil from deflation). Photos 5 and 6 show degraded and improved areas of the sandy forestry zone of the Karakul region.

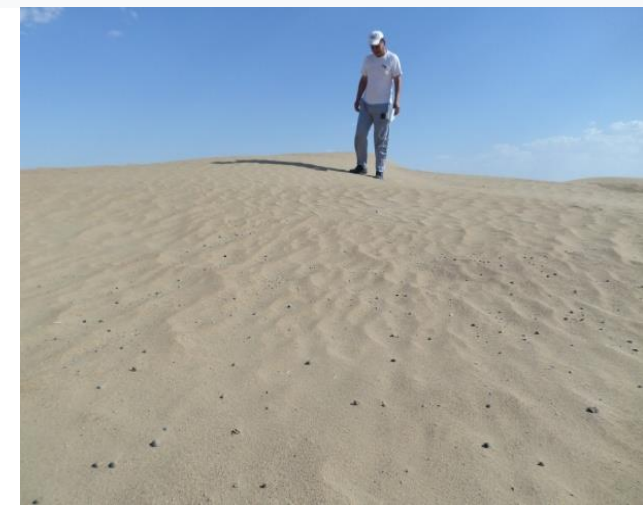

Photo 5. Degraded areas

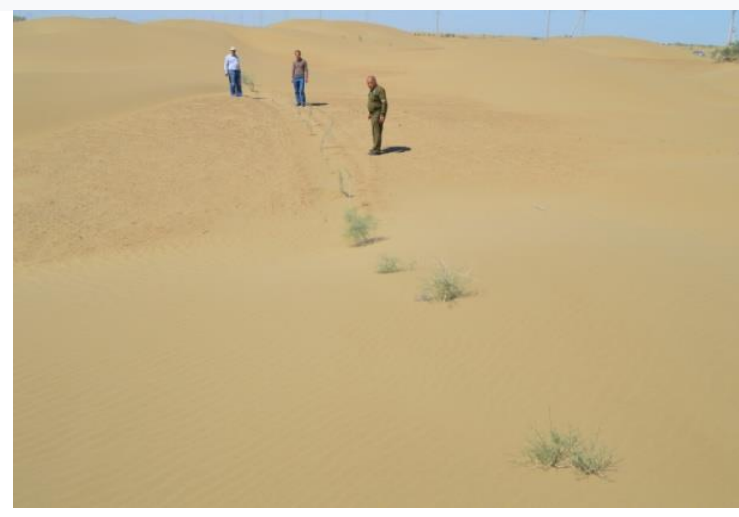

Photo 6. Seedlings after sowing

Within the framework of the Project, seedlings of Haloxylon aphyllum_and seeds of drought-resistant forage plants were planted in the Karakul Specialized State Forestry Enterprise on 300 hectares of land. The monitoring of the state of the plants showed that the seedlings and germinated seeds vegetate well.

Haloxylon aphyllum characterized by a high and stable yield of fodder mass, long productive longevity (25-35 years). In multicomponent agrocenoses, it significantly reduces the wind speed, retains snow, increasing the relative humidity of the air, thereby creating a special microclimate that favorably affects the growth and development of plants in the lower tiers. The yield of air-dry fodder mass in different years is $1.34-1.26 \mathrm{t} / \mathrm{ha}$, the seed yield is $0.05-0.13 \mathrm{t} / \mathrm{ha} .100 \mathrm{~kg}$ of dry mass contains 45.5 fodder units. [4]

Haloxylon persicum Bge is a shrub from the family of Chenopodiacea, 3-4 $\mathrm{m}$ high, with a thick, gnarled gray-brown trunk. It develops a powerful and deeply penetrating root system that uses moisture at a depth of 3-20 m. Haloxylon aphyllum is a valuable desert plant that provides food for sheep and camels. It has an important meliorative value as an excellent sand strengthening agent. Sheep willingly eat it in autumn and winter, weakly in spring and summer. It is well eaten by camels all year round. The parts eaten are assimilation shoots and seeds.

Seeds of Haloxylon persicum -fattening feed for Karakul sheep. Eaten shoots contain 2.7-9.8\% protein, 12.6-26.3\% fiber, 24.6-40.5\% NES (No nitrogen Extractive Substances). Nutritional value of feed 52 fodder units per $100 \mathrm{~kg}$ of dry weight. Digestibility ratio of protein 52, fiber 47, fat 29, organic matter $56 \%$. Under natural conditions, white Haloxylon persicum grows slowly, the yield of fodder mass is small, -0,2-0,4 t/ha of dry fodder. In culture, it grows relatively quickly; its height in the first year of life is $35-40 \mathrm{~cm}$, in the second-third years $60-150 \mathrm{~cm}$. The yield of dry fodder mass in a culture is $0.3-$ $0.5 \mathrm{t} / \mathrm{ha}$. Haloxylon persicum is a promising plant for creating pasture agrophytocenoses in sandy deserts.

Salsola paletzkiana Litv. - tree-like shrubs from the Chenopodiacea family, 3-5 m high, are typical psammophytes, in nature they are distributed mainly in a sandy desert, they are often landscape species (photo 7).

The feeding properties of the Salsola paletzkiana_have been studied quite well (Shamsutdinov, 1975; Mukhammedov, 1979; Karibaev et al., 2000). On the dry food contains 19-20.3 protein, 2.8-2.9\% fat,

147 | P a g e

www.iiste.org 
14-17\% ash, 42-47\% NES (No nitrogen Extractive Substances) and 15-17\% fiber. $100 \mathrm{~kg}$ of dry mass, depending on the seasons of the year, contains from 33 to 45 fodder units.

According to K.K. Karibaev et al. (2000) in Salsola paletzkiana fodder contains 0.55 fodder units, while in alfalfa hay this indicator is 0.43 . Thus, the introduction of the Salsola paletzkiana_into the culture in a gypsum desert not only contributes to an increase in the productivity of pastures, but also significantly improves the quality of pasture fodder. In the first year, the height of individual plants reaches $80-100 \mathrm{~cm}$. The root system of the Salsola paletzkiana is of a universal type. It develops differently depending on soil conditions. There is evidence that in a sandy desert, where groundwater is located deep enough, the roots of the Salsola paletzkiana develops mainly in a horizontal direction.

In hilly sands with groundwater at a depth of 8-10 m, the roots of Salsola paletzkiana are directed vertically, reaching moist horizons (Petrov, 1933). Excavation of the root systems of 4-year-old individuals of the Salsola paletzkiana showed that the main root penetrates into the soil up to $6 \mathrm{~m}$ depth, the lateral roots go to the sides from the main one by $1.5-2.5 \mathrm{~m}$. The specific type of development of the root system of the Salsola paletzkiana species in various soil conditions indicates its high adaptive potential. Under the conditions of culture, the height of the plants of the Salsola paletzkiana at the age of four reached $2.3 \mathrm{~m}$, forming many shoots of the second, third orders. Crown width size is $1.7 \times 2.0 \mathrm{~m}$.

The fodder productivity of Salsola paletzkiana species in different conditions fluctuates in different ranges. According to N.S. Zaprometova (1956) in Kyzylkum desert, the seed productivity of 1 Salsola paletzkiana shrubs is on average $200 \mathrm{~g}$, the maximum is $2 \mathrm{~kg}$. The yield of the fodder mass of the Salsola paletzkiana in culture is directly dependent on the density of its standing. Individual fodder productivity of the Salsola paletzkiana in the fourth year of life fluctuates between $3.5-6.2 \mathrm{~kg}$ per bush, and in the structure of the fodder yield a high proportion (up to 72\%) belongs to the seed fraction. The potential forage productivity of the Salsola paletzkiana is quite high and directly depends on the density of its standing on one hectare.

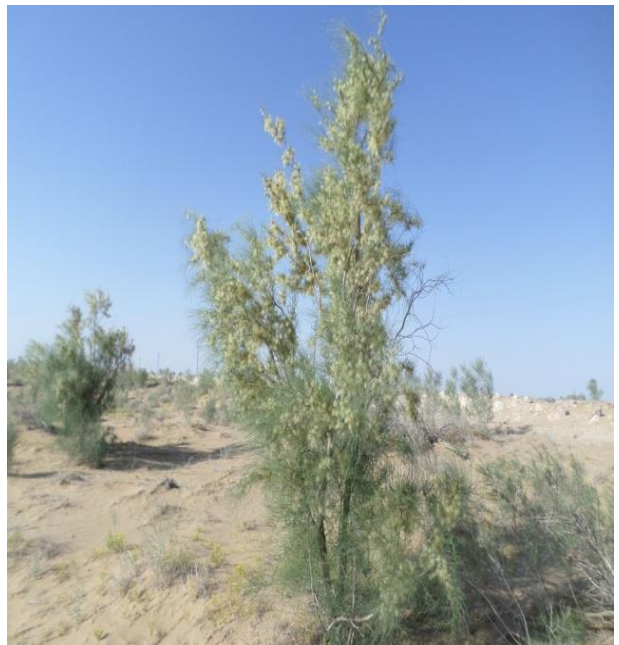

Photo 7. Salsola paletzkiana

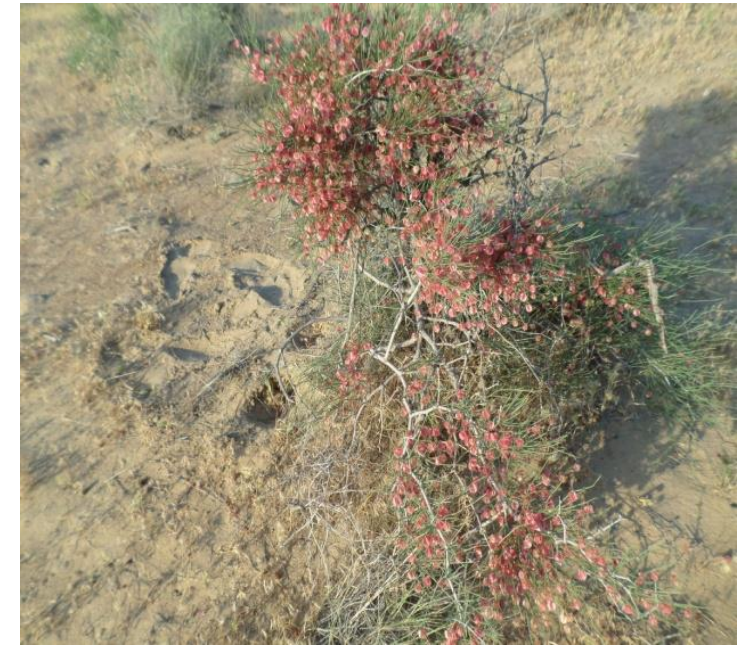

Photo 8. Calligonum setosum

Calligonum species are shrubs up to 2-3 meters high, belonging to the Polygonaceae family. Among the species belonging to this family, there are species with upright stems Calligonum caput-medusae or branched Calligonum microcarpa, Calligonum setosum (photo 8). In total, 47 species of representatives of the Calligonum family can be found in Uzbekistan (Khaidarov, Khodzhimatov, 1992). Calligonum leaves are narrow, fibrous, 3-5 mm long, fall off early. Seed development continues from March to May. Blooms are in April-May. Fruits ripen in June, 20-30 mm long, 18-27 mm wide, yellow or red.

All Calligonum species are valuable forage plants for sheep, goats and camels. Green twigs and seeds are the main edible parts, and during the flowering period the feed contains up to $12.5 \%$ protein, $19.4 \%$ ash, 34.4\% NES (No nitrogen Extractive Substances), 30\% fiber. It was found that $100 \mathrm{~kg}$ of dry weight contains $61.5-87.1 \mathrm{mg} / \mathrm{kg}$ of carotene and $3668-5657 \mathrm{mg} / \mathrm{kg}$ of vitamin C (Kalenov, 1961). 100 $\mathrm{kg}$ of dry mass food contains 71.8 fodder units. On natural pastures, with the number of Calligonum bushes per hectare 100-300, the yield of hay can be $0.1 \mathrm{t} / \mathrm{ha}$. Calligonum species live $15-20$ years and

148 | P a g e

www.iiste.org 
form high yields of forage mass. Under crop conditions, the yield is $0.9-1.6 \mathrm{t} / \mathrm{ha}$. Calligonum is a promising plant for strengthening moving sands.

In the Karakul region, planting of seedlings and sowing of seeds were carried out on an area of 300 hectares, with inter-lane spaces of 9 meters. Haloxylon saplings are planted along furrows $1 \mathrm{~m}$ wide, in the same furrows, in addition to obtaining guaranteed seedlings, Haloxylon persicum_seeds are sown. Pasture protection belts are laid 10-25 m wide from large shrubs (Haloxylon persicum, Salsola paletzkiana and Calligonum), with a density of 600-1200 pcs/ha. On flat massifs, stripes are located perpendicular to the direction of the prevailing winds, on foothills - across slopes and ridges. Natural pastures are left between the strips. With this arrangement, for every 100 hectares of pastures, there are 10.0 - 12.5 hectares of protective zones.

The seeding rate of Haloxylon persicum is $5 \mathrm{~kg} / \mathrm{ha}$, Salsola paletzkiana_10-12 kg/ha, Calligonum 6-7 $\mathrm{kg} / \mathrm{ha}$. The technology provides benefits after 3-4 years, and farmers can distribute seeds and expand their crops at no additional cost.

The main problems to be solved by the technology are the degradation of land resources, including soil, water, plant and animal resources, wind erosion and biological degradation.

The measures to maintain the vegetation cover ensure the longevity of the forest Defensive strip for 4060 years; to maintain the technology, no additional investments are required. The technology is lowcost; therefore, the result obtained in comparison with investments is already positive in the short term. All activities for the preparation of land, sowing and care of crops are traditional. [5]

\section{Benefits of introducing technology:}

Creation of pasture protection belts will increase the productivity of pastures by 2-3 times and, accordingly, increase the profitability of forage production. The biodiversity of vegetation, animals and birds increases in the spaces between stripes. In the foothill zone, the slopes of hills prone to water erosion are strengthened, the water regime is improved and the upper fertile layer of the earth is preserved. Sand dunes are fixed in the desert zone.

The plantations created will allow the use of pastures in all seasons of the year, increase soil fertility, sequestration of CO2 $-480 \mathrm{~kg}$ per $1 \mathrm{ha}$, and improve the environment. Contributes to the creation of a system of pasture use adapted to the conditions of global climate change.

\section{Conclusions.}

Rational use of desert pastures, preservation of biodiversity, consistent increase in the productivity of pastures by under sowing plants, the introduction of technologies to increase the productivity of pastures ensure the longevity of defensive strip for a long time. The measures to maintain the vegetation cover ensure the longevity of the forest defensive strip for 40-60 years

\section{REFERENCES}

1.Gaevskaya L.S. Karakul pastures of Central Asia. Tashkent. FAN. 1971, 333 p. (Russ)

2.Nazaryuk L.A. Results and prospects of breeding izen (Kochia) in Central Asia. - in collection: State and prospects of selection and introduction of forage plants for desert and semi-desert zones. Samarkand, 1979, p. 14-16. (Russ)

3. Guidelines for the geobotanical survey of natural forage lands in Uzbekistan, $1980-170 \mathrm{p}$. (Russ)

4. Rabbimov A., Mukimov T., Babaeva A. et al. Introduction and breeding bases for increasing the productivity of arid pastures in Uzbekistan. Agrarian science - agriculture. IX International Scientific and Practical Conference. Barnaul 2014, 227-229 p. (Russ)

5. Mukimov T. UNDP report, project "Land", Tashkent, 2019, 48 p. (Russ) 